\title{
Increased Sphingomyelin Content of Plasma Lipoproteins in Apolipoprotein E Knockout Mice Reflects Combined Production and Catabolic Defects and Enhances Reactivity with Mammalian Sphingomyelinase
}

\author{
Tae-sook Jeong, ${ }^{\star}$ Scott L. Schissel, ${ }^{\star \ddagger}$ Ira Tabas, ${ }^{\star \ddagger}$ Henry J. Pownall, ${ }^{\S}$ Alan R. Tall, ${ }^{\star}$ and Xian-cheng Jiang ${ }^{\star}$ \\ $*$ Division of Molecular Medicine, Department of Medicine, and Department of Anatomy and Cell Biology, College of Physicians \& \\ Surgeons, Columbia University, New York, New York 10032; and ${ }^{\S}$ Department of Medicine and Department of Molecular Physiology and \\ Biophysics, Baylor College of Medicine, Houston, Texas 77030
}

\begin{abstract}
Apolipoprotein E knockout (apoE0) mice accumulate atherogenic remnant lipoproteins in plasma. We now provide evidence that these particles are enriched in sphingomyelin (SM), and explore the mechanisms and possible pathophysiological consequences of this finding. The phosphatidylcholine/sphingomyelin (PC/SM) ratio was reduced in all lipoproteins in apoE0 mice compared with wild-type $(\mathrm{Wt})$ mice $(2.0 \pm 0.2$ vs. $4.7 \pm 0.5 ; 2.8 \pm 0.5$ vs. $5.5 \pm 0.9 ; 1.9 \pm 0.5$ vs. 4.6 \pm 0.5 for VLDL, LDL, and HDL), reflecting 400 and $179 \%$ increases in plasma pools of SM and PC, respectively. Turnover studies using $\left[{ }^{14} \mathrm{C}\right] \mathrm{PC} /\left[{ }^{3} \mathrm{H}\right] \mathrm{SM}$ VLDL or HDL showed that the fractional catabolic rate (FCR) of VLDLSM and HDL-SM were markedly reduced in the apoE0 mice compared with Wt mice, while the FCRs of VLDL-PC and HDL-PC were similar. By contrast, the FCRs of $\left[{ }^{3} \mathrm{H}\right] \mathrm{PC}$ ether and $\left[{ }^{14} \mathrm{C}\right] \mathrm{SM}$ were identical in apoE0 and $\mathrm{Wt}$ mice. The production rates of VLDL-SM and HDL-SM in apoE0 mice were much higher than in $\mathrm{Wt}$ mice, while the production rates of lipoprotein $\mathrm{PC}$ were similar. To assess the underlying mechanisms, we also measured the $\mathrm{PC} / \mathrm{SM}$ ratio in VLDL and LDL of LDL receptor knockout (LDLr0) and hepatic LDL receptor-related protein knockout/LDLr0 mice, but found no difference with Wt mice. Using S-sphingomyelinase, an enzyme secreted by macrophages and endothelial cells, we found that VLDL and LDL from apoE0, but not from Wt or LDLr0 mice, were significantly aggregated, and that aggregation was not prevented by adding back apoE. We then enriched the apoE0-VLDL and Wt-VLDL with different amounts of SM, and found that VLDL aggregation was enhanced. Thus, the increased SM content of lipoproteins in apoE0 mice is due to combined synthesis and clearance defects. Impaired SM clearance reflects resistance to intravascular enzymes and delayed removal by a non-LDLr, non-LDLr related protein pathway. The increased SM content in slowly cleared remnant lipoproteins may enhance
\end{abstract}

Address correspondence to Xian-Cheng Jiang, Ph.D., Division of Molecular Medicine, Department of Medicine, Columbia University, 630 West 168th Street, New York, NY 10032. Phone: 212-305-7720; FAX: 212-305-5052; E-mail: xcj1@columbia.edu

Received for publication 9 June 1997 and accepted in revised form 19 December 1997.

J. Clin. Invest.

(C) The American Society for Clinical Investigation, Inc. 0021-9738/98/02/0905/08 \$2.00

Volume 101, Number 4, February 1998, 905-912

http://www.jci.org their susceptibility to arterial wall SMase and increase their atherogenic potential. (J. Clin. Invest. 1998. 101:905-912.) Key words: sphingomyelin $\bullet$ sphingomyelinase $\bullet$ phosphatidylcholine $\bullet$ apolipoprotein $\mathrm{E} \bullet$ atherosclerosis

\section{Introduction}

Sphingomyelin (SM), ${ }^{1}$ which is the second most abundant phospholipid in mammalian plasma, appears in all major lipoproteins where it is part of the monolayer of polar lipids and cholesterol that surrounds a core of neutral lipids. Up to $18 \%$ of the total plasma phospholipid occurs as SM (1), and the ratio of phosphatidylcholine (PC)/SM varies widely among lipoprotein subclasses $(2,3)$. Atherogenic lipoproteins such as VLDL remnants accumulating in cholesterol-fed rabbits tend to be SM-enriched (4). The SM content of atherosclerotic lesions is higher than that of normal arterial tissue, and SM accumulation is disproportionate to that of $\operatorname{PC}(5,6)$. However, the role of SM deposited or synthesized in atheromata remains undefined.

Animal models provide one useful approach to studies of atherogenic mechanisms. Using transgenic techniques, atherogenic or cardioprotective genes can be deleted or inserted to test the role of specific proteins in atherogenesis in vivo (7). The apolipoprotein E knockout apoE0 mouse does not express apoE, a plasma apolipoprotein that is required for uptake of lipoproteins via the LDL receptor (LDLr) or the LDL receptor-related protein (LRP). ApoE0 mice exhibit hypercholesterolemia that is distinguished by accumulation of cholesterol-enriched apoB-containing lipoproteins (8). ApoE0 mice develop complex atherosclerotic lesions in response to a chow diet $(9,10)$, and may also display features of Alzheimer's disease including memory deficits and cholinergic impairment (11).

Atherogenesis is initiated by interaction of cholesterol-rich lipoproteins with the arterial wall (12). Many processes have been implicated in early atherogenesis. These include lipoprotein oxidation $(13,14)$, lipoprotein retention and aggregation $(12,15)$, endothelial alteration (16), macrophage chemotaxis and foam cell formation (16), and smooth muscle cell migration and alteration (16). Subendothelial retention and aggrega-

1. Abbreviations used in this paper: ApoE0, apolipoprotein $\mathrm{E}$ gene knockout; FCR, fractional catabolic rate; HL, hepatic lipase; LCAT, lecithin/cholesterol acyltransferase; LDLr, LDL receptor; LDLr0, LDL receptor knockout; LRP, LDL receptor-related protein; LRP0, LRP knockout; PC, phosphatidylcholine; PLTP, phospholipid transfer protein; PR, production rates: S-SMase, secreted SMase; SM, sphingomyelin; SPT, serine/palmitoyltransferase; Wt, wild-type. 
tion of atherogenic lipoproteins have emerged as central pathogenic processes in atherogenesis (12). LDL extracted from atherosclerotic lesions is aggregated or has an increased tendency to aggregate, whereas plasma LDL exposed to the same procedure does not aggregate $(17,18)$. LDL retained in atherosclerotic lesions is acted upon by an arterial wall SMase, which appears to promote aggregation by generating ceramide (6). A leading candidate for this arterial wall enzyme is a $\mathrm{Zn}^{2+}$ dependent SMase that is secreted by cultured macrophages (19) and endothelial cells (Schissel et al., manuscript in preparation), which are major constituents of atherosclerotic lesions. The secreted SMase (S-SMase) is derived from the same gene and mRNA as that encoding lysosomal SMase (19).

During studies of plasma phospholipid metabolism in transgenic mice (20), we discovered that the plasma lipoproteins of apoE0 mice were markedly enriched in SM. This report describes these findings and defines mechanisms responsible for the increased SM content of lipoproteins in apoE0 mice, and the impact of these compositional changes on interaction with mammalian SMase.

\section{Methods}

Materials. $\left[9,10-{ }^{3} \mathrm{H}\right]$ Palmitic acid and L-a-1-palmitoyl-2-oleoyl-[oleoyl-1- $\left.{ }^{14} \mathrm{C}\right]$ phosphatidyl choline were obtained from DuPont-NEN (Boston, MA). Sphingomyelinase (from Bacillus cereus) was obtained from Sigma Chemical Co. (St. Louis, MO). [ $N$-palmitoyl-9,10$\left.{ }^{3} \mathrm{H}\right] \mathrm{SM}$ and $\left[{ }^{3} \mathrm{H}\right] \mathrm{POPC}$ ether were synthesized as previously described $(6,21)$.

Lipoproteins. VLDL, LDL, and HDL were isolated from fresh mouse plasma by preparative ultracentrifugation using an Optima TL ultracentrifuge (model TLA 100.4; Beckman Instruments, Inc., Fullerton, CA). Plasma VLDL and HDL were labeled with $\left[{ }^{3} \mathrm{H}\right] \mathrm{SM}$ and $\left[{ }^{14} \mathrm{C}\right] \mathrm{PC}$ as follows: labeling of VLDL: $100 \mathrm{mCi}(2.3 \mathrm{nmol})$ of [ $N$-palmitoyl-9,10- ${ }^{3} \mathrm{H}$ ]SM and $10 \mathrm{mCi}$ of L-a-1-palmitoyl-2-oleoyl-[oleoyl-1$\left.{ }^{14} \mathrm{C}\right] \mathrm{PC}$ were mixed, and the solvent was removed under a stream of nitrogen. The dried phospholipids were resuspended in $150 \mu \mathrm{l} \mathrm{EtOH}$ and slowly injected into a stirred 6-ml solution of VLDL (2 mg total phospholipid) through a 25 -gauge needle. The VLDL solution was then incubated with $1.5 \mathrm{ml}$ partially purified phospholipid transfer protein (PLTP; $0.5 \mathrm{mg}$ protein $/ \mathrm{ml}$ ) or $1.5 \mathrm{ml} \mathrm{d}>1.21 \mathrm{~g} / \mathrm{ml}$ fraction $(15$ $\mathrm{mg}$ protein/ml), which contained PLTP activity with $1.5 \mathrm{mM} 5,5^{\prime}$-dinitro-bis (2-nitro benzoic acid; to inactivate lecithin/cholesterol acyltransferase [LCAT] activity) for $8 \mathrm{~h}$ at $37^{\circ} \mathrm{C}$ in a shaking water bath. $\left[{ }^{3} \mathrm{H}\right] \mathrm{SM} /\left[{ }^{14} \mathrm{C}\right] \mathrm{PC}-$-labeled VLDL was then separated from the incubation mixture by ultracentrifugation at $\mathrm{d}=1.02 \mathrm{~g} / \mathrm{ml}$ for $4 \mathrm{~h}$ at 98,000 $\mathrm{rpm}$ in a rotor (model TLA 100.4; Beckman Instruments) and dialyzed against PBS. Plasma HDL was labeled using the same method as VLDL. Both $\left[{ }^{3} \mathrm{H}\right] \mathrm{SM} /\left[{ }^{14} \mathrm{C}\right] \mathrm{PC}$-labeled VLDL and $\mathrm{HDL}$ were stored under argon at $4^{\circ} \mathrm{C}$ and used within 1 wk of preparation.

$S M, P C$ assays. Lipid extracts (22) of lipoproteins were separated by TLC on silica gel (Adsorbosil plus1; Alltech Associates, Inc., Deerfield, IL) using chloroform/methanol/acetic acid/ $\mathrm{H}_{2} \mathrm{O}$ (50:25:8:4; $\mathrm{vol} / \mathrm{vol} / \mathrm{vol} / \mathrm{vol}$ ). Individual phospholipid subclasses were visualized by iodine vapor staining, and the SM and PC spots were identified by comparison with standards. The spots were scraped, extracted twice with choroform $/ \mathrm{methanol} / \mathrm{H}_{2} \mathrm{O}(5: 10: 4 ; \mathrm{vol} / \mathrm{vol} / \mathrm{vol})$, and assayed for phosphate content by the method of Bartlett (23). Total plasma phospholipids were also assayed by enzymatic assay based on detection of choline (24).

In vivo turnover studies. Mice were injected intravenously (femoral vein) with apoE0-VLDL or apoE0-HDL labeled with $\left[{ }^{3} \mathrm{H}\right] \mathrm{SM}$ and $\left[{ }^{14} \mathrm{C}\right] \mathrm{PC}\left(7.5-11.0 \times 10^{5} \mathrm{cpm}\right.$ and $6.5-9.5 \times 10^{5} \mathrm{cpm}$, respectively). Blood $(70 \mu \mathrm{l})$ was taken from the tail vein at $10 \mathrm{~min}, 30 \mathrm{~min}, 1 \mathrm{~h}, 2 \mathrm{~h}$, $4 \mathrm{~h}, 8 \mathrm{~h}$, and $24 \mathrm{~h}$ for determination of radioactivity. The fractional catabolic rates (FCR) for SM and PC were calculated from the decay curves of $\left[{ }^{3} \mathrm{H}\right] \mathrm{SM}$ and $\left[{ }^{14} \mathrm{C}\right] \mathrm{PC}$ radioactivity in whole plasma and in VLDL and HDL fraction after isolation by ultracentrifugation according to the Matthews method (25). The production rates (PR) were calculated by multiplying the FCR by the plasma pool and dividing by the body weight (26).

SM-enriched apoEO-VLDL preparation. (a) $\mathrm{PC} / \mathrm{SM} / \mathrm{FC}$ vesicles were prepared as follows: $12 \mathrm{mg} \mathrm{SM}$ (in $5 \mathrm{ml} \mathrm{CHCl}_{3}$ ), $12 \mathrm{mg} \mathrm{PC} \mathrm{(in}$ $150 \mathrm{ml} \mathrm{EtOH}$ ), and $6 \mathrm{mg}$ cholesterol (in $1 \mathrm{ml} \mathrm{EtOH}$ ) were mixed, dried under $\mathrm{N}_{2}$, and lyophilized for $18 \mathrm{~h}$. The dried lipids were resuspended in $6 \mathrm{ml}$ of PBS and sonicated under a stream of $\mathrm{N}_{2}$ at $40^{\circ} \mathrm{C}$ until translucent (40 $\mathrm{min})$. The sonicated material was then centrifuged twice at 15,000 $\mathrm{g}$, and the supernatant was harvested. (b) VLDL (4.5 $\mathrm{ml} \mathrm{d}<1.006 \mathrm{~g} / \mathrm{ml}$, total cholesterol $2 \mathrm{mg} / \mathrm{ml}$ ) from apoE0 mice was incubated with $5.7 \mathrm{ml} \mathrm{PC} / \mathrm{SM} / \mathrm{FC}$ vesicles and $5 \mathrm{ml} \mathrm{d}>1.21 \mathrm{~g} / \mathrm{ml}$ plasma (containing PLTP activity) for $0,1,2$, and $4 \mathrm{~h}$. The VLDL then was isolated by ultracentrifugation after incubation, and the PC/SM ratio was determined.

Atherogenic lipoproteins aggregation assay. Lipoprotein aggregation was assessed as described previously (2). In brief, VLDL or LDL ( $4 \mu \mathrm{g}$ cholesteryl ester) was incubated with $50 \mathrm{mU} / \mathrm{ml}$ B.cereus SMase in PBS buffer containing $5 \mathrm{mM} \mathrm{MgCl}$ or $25 \mathrm{ml}$ macrophage culture medium containing S-SMase in $0.1 \mathrm{M}$ Tris- $\mathrm{HCl}$ buffer, $\mathrm{pH} 7.2$, at $37^{\circ} \mathrm{C}$ for $4 \mathrm{~h}$. The turbidity of samples was assessed by measuring the OD at $430 \mathrm{~nm}$

Serine/palmitoyl transferase (SPT) assay. Preparation of mouse liver microsome and measurements of SPT activity were performed as described previously (27).

$R$ Nase protection assay for the Lcb2 subunit of SPT. Total RNA $(30 \mu \mathrm{g})$ from the liver of apoE0 and wild-type mice was analyzed for the Lcb2 subunit of SPT mRNA (28) by a solution hybridizationribonuclease protection assay (29) using riboprobe highly specific for mouse. The riboprobe (216 nucleotides) for Lcb2 subunit of SPT contains a portion of the vector (Bluescript $\mathrm{KS}+$ ), and is complementary to 156 nucleotides of the 3 -untranslated region of the mouse Lcb2 subunit mRNA.

Statistical analysis. Results are expressed as mean \pm SD.

\section{Results}

The chow-fed apoE0 mice had severe hypercholesterolemia as reported previously $(7,8$; Table I). We found that total plasma choline-containing phospholipids were also markedly increased in apoE0 mice compared with wild-type (Wt) mice (Table I). We then determined PC and SM mass by phosphate analysis of lipids extracted from plasma and lipoprotein fractions of apoE0 and Wt mice. The SM concentration in apoE0

Table I. Concentration of Cholesterol and Phospholipid in Plasma and Lipoproteins of Wild-type and apoE Knockout Mice

\begin{tabular}{|c|c|c|c|c|c|c|}
\hline & \multicolumn{2}{|c|}{ Cholesterol } & \multicolumn{2}{|c|}{ Phospholipids } & \multicolumn{2}{|c|}{$\mathrm{PC} / \mathrm{SM}$} \\
\hline & $\mathrm{Wt}$ & ApoE0 & $\mathrm{Wt}$ & ApoE0 & $\mathrm{Wt}^{\S}$ & ApoE0 \\
\hline & $m g / d l$ & $m g / d l$ & $m g / d l$ & $m g / d l$ & & \\
\hline Plasma & $78 \pm 13$ & $526 \pm 65^{*}$ & $185 \pm 36$ & $385 \pm 29 *$ & $5.2 \pm 0.7$ & $2.3 \pm 0.1^{*}$ \\
\hline VLDL & $4 \pm 2$ & $198 \pm 16^{*}$ & $8 \pm 3$ & $109 \pm 29 *$ & $4.7 \pm 0.5$ & $2.0 \pm 0.2 *$ \\
\hline LDL & $12 \pm 5$ & $201 \pm 27 *$ & $29 \pm 11$ & $141 \pm 33 *$ & $5.5 \pm 0.9$ & $2.8 \pm 0.5 *$ \\
\hline HDL & $52 \pm 7$ & $41 \pm 9 *$ & $130 \pm 31$ & $86 \pm 8 *$ & $4.6 \pm 0.9$ & $1.9 \pm 0.5 *$ \\
\hline
\end{tabular}

VLDL $(\mathrm{d}<1.006 \mathrm{~g} / \mathrm{ml})$; LDL (1.006-1.063 g/ml); HDL (1.063-1.21 g/ml). $* P<0.001$ (Wt vs. apoE0 mice). ${ }^{*}$ Determined by enzymatic assay of choline-containing phospholipids. ${ }^{\S}$ Determined by phosphate analysis after separation of extracted lipids by TLC. 
mouse plasma was markedly higher ( $\sim$ fourfold) than in $\mathrm{Wt}$ mice $(99 \pm 6 \mathrm{mg} / \mathrm{dl}$ vs. $24 \pm 5 \mathrm{mg} / \mathrm{dl}, P<0.001)$, whereas PC concentration was only about 1.8 -fold higher $(226 \pm 33 \mathrm{mg} / \mathrm{dl}$ vs. $125 \pm 12 \mathrm{mg} / \mathrm{dl}, P<0.001)$. Thus, the plasma $\mathrm{PC} / \mathrm{SM}$ ratio in apoE0 mice was $\sim 2.3$, whereas in $\mathrm{Wt}$ mice the ratio was $\sim 5.2$ (Table I). Separation of plasma lipoproteins showed that the $\mathrm{PC} / \mathrm{SM}$ ratio was decreased in all lipoprotein classes of apoE0 mice, including HDL (Table I).

To identify the mechanisms responsible for increased SM concentration in the circulation, PC and SM turnover studies
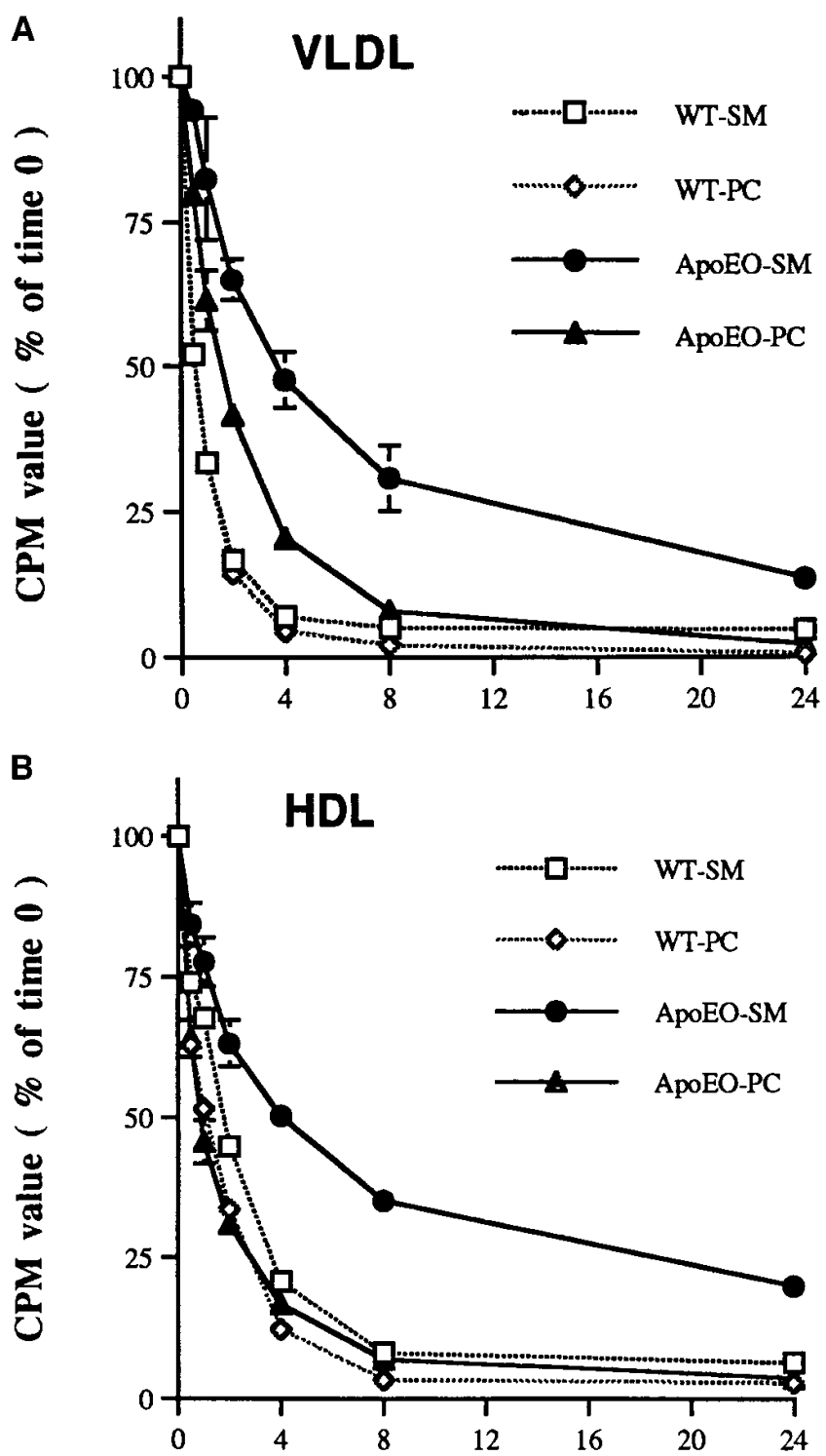

TIME ( hour )

Figure 1. Radioactivity decay curves for $\left[{ }^{3} \mathrm{H}\right] \mathrm{SM} /\left[{ }^{14} \mathrm{C}\right] \mathrm{PC}-\mathrm{VLDL}$ and $\left[{ }^{3} \mathrm{H}\right] \mathrm{SM} /\left[{ }^{14} \mathrm{C}\right] \mathrm{PC}-\mathrm{HDL}$ in Wt and apoE0 mice. Mice were injected intravenously with $\left[{ }^{3} \mathrm{H}\right] \mathrm{SM} /\left[{ }^{14} \mathrm{C}\right] \mathrm{PC}-\mathrm{VLDL}$ or $\left[{ }^{3} \mathrm{H}\right] \mathrm{SM} /\left[{ }^{14} \mathrm{C}\right] \mathrm{PC}-\mathrm{HDL}$, and $70 \mu \mathrm{l}$ of blood was taken from the tail vein at $10 \mathrm{~min}, 30 \mathrm{~min}, 1 \mathrm{~h}$, $2 \mathrm{~h}, 4 \mathrm{~h}, 8 \mathrm{~h}$, and $24 \mathrm{~h} .35 \mu \mathrm{l}$ of plasma was used for radioactivity measurement. These results are representative of six similar experiments. (A) $\left[{ }^{3} \mathrm{H}\right] \mathrm{SM} /\left[{ }^{14} \mathrm{C}\right] \mathrm{PC}-\mathrm{VLDL} ;(B)\left[{ }^{3} \mathrm{H}\right] \mathrm{SM} /\left[{ }^{14} \mathrm{C}\right] \mathrm{PC}-\mathrm{HDL}$.
Table II. SM and PC FCR in Wild-type and ApoE Knockout Mice

\begin{tabular}{lccc}
\hline Recipient mouse & ApoE0 Lp & SM & PC \\
\hline & & pools $/ h$ & pools $/ h$ \\
Wt & VLDL & $0.304 \pm 0.033^{*}$ & $0.338 \pm 0.089$ \\
ApoE0 & VLDL & $0.128 \pm 0.023^{*}$ & $0.250 \pm 0.065$ \\
Wt & HDL & $0.273 \pm 0.046^{\ddagger}$ & $0.334 \pm 0.074^{\S}$ \\
ApoE0 & HDL & $0.113 \pm 0.019^{\ddagger}$ & $0.273 \pm 0.038^{\S}$
\end{tabular}

ApoE0 Lp, lipoproteins from apoE knockout mouse. ${ }^{*} P=0.001 ;{ }^{\ddagger} P=$ $0.001 ;{ }^{\S} P=0.02(n=5-7)$.

were performed. We labeled VLDL or HDL from apoE0 mice (apoE0-VLDL or apoE0-HDL) using $\left[{ }^{3} \mathrm{H}\right] \mathrm{SM}$ and $\left[{ }^{14} \mathrm{C}\right] \mathrm{PC}$, and injected the lipoproteins into both apoE0 and Wt mice. As shown by the decay curves in Fig. $1, A$ and $B$, for $\left[{ }^{3} \mathrm{H}\right] \mathrm{SM} /$ $\left[{ }^{14} \mathrm{C}\right] \mathrm{PC}$-labeled VLDL and HDL, respectively, the FCRs of $\left[{ }^{3} \mathrm{H}\right] \mathrm{SM}-\mathrm{VLDL}$ and $\left[{ }^{3} \mathrm{H}\right] \mathrm{SM}-\mathrm{HDL}$ were greatly reduced in apoE0 mice compared with Wt mice (2.4- and 2.4-fold reductions, respectively; Table II). By contrast, the FCRs of $\left[{ }^{14} \mathrm{C}\right] \mathrm{PC}-\mathrm{VLDL}$ and $\left[{ }^{14} \mathrm{C}\right] \mathrm{PC}-\mathrm{HDL}$ were only slightly reduced (1.4- and 1.2-fold) in apoE0 mice compared with that of the control animals (Fig. 1, Table II). The turnover curves of PC and SM were similar for VLDL and HDL (Fig. 1, $A$ and $B$ ), consistent with observed rapid equilibration of radiolabeled phospholipid between lipoproteins after injection (data not shown). Based on the FCR, body weight, and pool size, we calculated the production rates (PR) of HDL-SM, VLDL-SM, HDL-PC, and VLDL-PC. Interestingly, the PR of VLDL-SM and HDL-SM were higher than in control mice (Table III; 2.3- and 2.2-fold increase, respectively), while the PR of HDL-PC and VLDL-PC were only increased 1.4- and 1.3-fold, respectively (Table III). Thus, the fourfold increase in the plasma pool of SM in apoE0 mouse is due to the combined effects of an approximately twofold decrease of FCR and twofold increase of PR.

One possible explanation for the disproportionate delay in clearance of SM compared with PC is that PC may undergo intravascular catabolism because of the actions of hepatic lipase (HL) and LCAT, whereas SM is not a substrate for these enzymes $(30,31)$. To evaluate this possibility, we compared the clearance of PC ethers to SM; PC ethers are also resistant to LCAT and HL $(30,32)$. Thus, $\left[{ }^{3} \mathrm{H}\right] \mathrm{POPC}$ ether and $\left[{ }^{14} \mathrm{C}\right] \mathrm{SM}-$ labeled apoE0-VLDL were injected into apoE0 and Wt mice.

Table III. Lipoprotein SM and PC PR in Wild-type and ApoE Knockout Mice

\begin{tabular}{lccc}
\hline Recipient mouse & Donor Lp & SM & PC \\
\hline & & $m g / g / h$ & $m g / g / h$ \\
Wt & VLDL & $8.5 \pm 1.9^{*}$ & $46.6 \pm 12.4$ \\
ApoE0 & VLDL & $19.6 \pm 3.2^{*}$ & $62.8 \pm 16.2$ \\
Wt & HDL & $7.6 \pm 1.3^{\ddagger}$ & $51.7 \pm 10.1^{\S}$ \\
ApoE0 & HDL & $16.8 \pm 3.9^{\ddagger}$ & $68.6 \pm 9.4^{\S}$
\end{tabular}

Donor lipoproteins were from apoE knockout mice. ${ }^{*} P<0.001$; ${ }^{\ddagger} P<$ $0.001 ;{ }^{\S} P<0.02(n=5-7)$. 


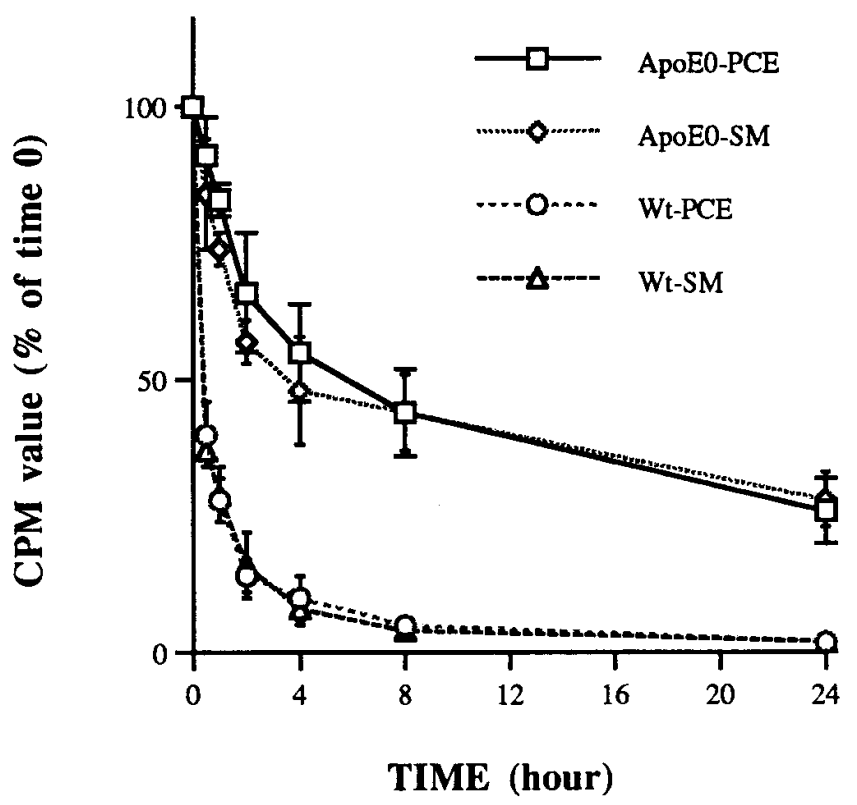

Figure 2. Radioactivity decay curves for $\left[{ }^{3} \mathrm{H}\right] \mathrm{POPC}$ ether $/\left[{ }^{14} \mathrm{C}\right] \mathrm{SM}$ labeled apoE0-VLDL in Wt and apoE0 mice. Mice were injected intravenously with $\left[{ }^{3} \mathrm{H}\right] \mathrm{POPC}$ ether/ $\left[{ }^{14} \mathrm{C}\right] \mathrm{SM}-\mathrm{VLDL} .70 \mu \mathrm{l}$ of blood was taken from the tail vein at $10 \mathrm{~min}, 30 \mathrm{~min}, 1 \mathrm{~h}, 2 \mathrm{~h}, 4 \mathrm{~h}, 8 \mathrm{~h}$, and $24 \mathrm{~h}$. $35 \mu l$ of plasma was used for radioactivity measurement. These results are representative of two similar experiments.

There was no difference in the decay curves of these two radiolabeled lipids (Fig. 2), indicating that the more rapid catabolism of PC compared with SM in Wt mice reflects intravascular catabolism of PC, but not SM.

To address potential receptors responsible for increased clearance of SM in Wt vs. apoE0 mice, we evaluated other mouse strains containing induced mutations in genes controlling VLDL and LDL catabolism. We measured the PC/SM ratio in lipoproteins obtained from apoCIII transgenic (apoCIII$\mathrm{Tg}$ ) mice and LDL receptor knockout (LDLr0) mice, which have clearance defects in VLDL and LDL $(33,34)$. However, neither apoCIII-Tg nor LDLr0 mice showed any alteration in $\mathrm{PC} / \mathrm{SM}$ ratio in apoB-containing lipoproteins or HDL (data not shown). Since the clearance of VLDL remnants is thought to involve a dual pathway involving LDL receptors and the LDL receptor-related protein (LRP; 35), we next evaluated LDLr0 + hepatic LRP knockout (LRP0) mice. The latter were generated by back-crossing LoxP-LRP mice with LDLr0 mice,

Table IV. The PC/SM Ratio in Lipoproteins of LDL Receptor and LDL Receptor/Conditional LRP Knockout Mice

\begin{tabular}{lcc}
\hline & \multicolumn{2}{c}{ PC/SM ratio } \\
\cline { 2 - 3 } \multicolumn{1}{c}{ Mice } & $\mathrm{d}<1.063 \mathrm{~g} / \mathrm{ml}$ & $\mathrm{d}=1.063-1.21 \mathrm{~g} / \mathrm{ml}$ \\
\hline $\mathrm{Wt}$ & $4.2,3.9$ & $6.0,6.2$ \\
LDLr0 & $5.2,4.6$ & $10.3,8.3$ \\
LDLr0 + LRP0 & $9.3,8.8$ & $8.4,10.1$ \\
& & \\
\hline
\end{tabular}

Values for duplicate mice are shown $(n=2)$. All mice were injected with cre-adenovirus.
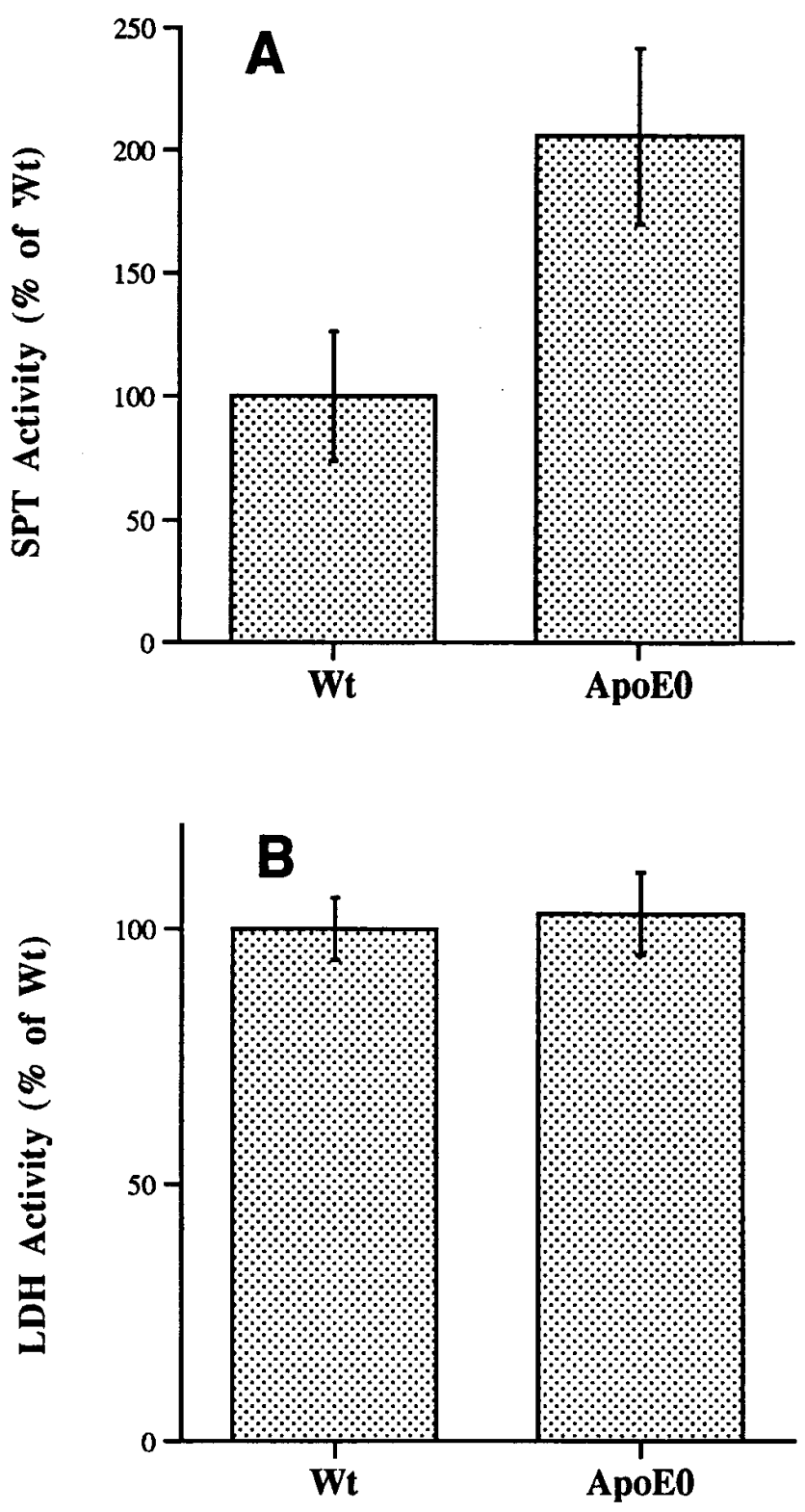

Figure 3. SPT activity in $\mathrm{Wt}$ and apoE0 mice. The SPT activity was determined as described in Methods $(n=6, P<0.001)$. Lactate dehydrogenase (LDH) was determined by using a kit from Sigma Chemical Co. (A) SPT measurement; (B) LDH measurement $(n=6)$.

and then adenovirus-Cre was injected into the mice. Thus, the liver LRP expression in these mice was specifically deleted. There was, however, no evidence of SM-enrichment of lipoproteins in these animals. In fact, the PC/SM ratio appeared to be increased in LDLr0, LRP0 mice (Table IV). These results are consistent with a third pathway (other than the LDL receptor and LRP) in the apoE-mediated clearance of SM-rich remnants.

To address the mechanism of increased SM production rates in E0 mice, we measured the hepatic activity of serine/ palmitoyl transferase (SPT), the enzyme that is thought to represent the rate-limiting step in the formation of sphingolipids (36). The liver microsomal SPT activity of apoE0 mice was about twofold higher than that of Wt mice (Fig. $3 A$ ), while 

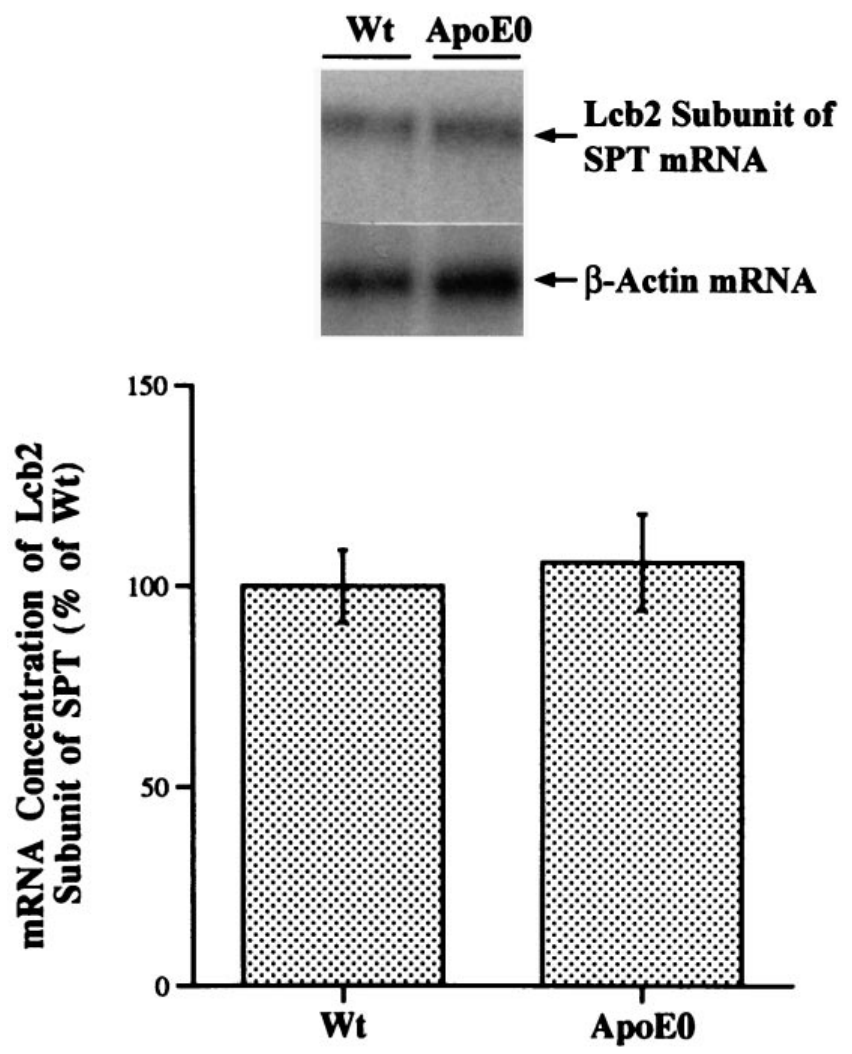

Figure 4. RNase protection assay for the Lcb2 subunit of SPT mRNA. Liver total RNA (30 mg) from wt and E0 mice was analyzed using a riboprobe specific for the mouse Lcb subunit of SPT that yields a protected fragment of 156 nucleotides $(n=6)$.
VLDL + LDL was supplemented with various amounts of exogenous apoE as described previously (47). In this experiment the apoB/apoE ratio (determined by gel scanning of SDS-PAGE gels at reisolated lipoproteins) was increased to the levels seen in VLDL + LDL from LDL receptor knockout mice (5:1). However, there was no significant effect of apoE supplementation on lipoprotein aggregation (Fig. 6).

To confirm that these results were specifically related to changes in the PC/SM ratio of the lipoproteins, we isolated VLDL from apoE0 mice plasma and enriched the particles with SM by incubation with $\mathrm{PC} / \mathrm{SM} / \mathrm{FC}$ vesicles. We then used the VLDL with a different PC/SM ratio to perform the in vitro aggregation using either bacterial SMase or macrophage-

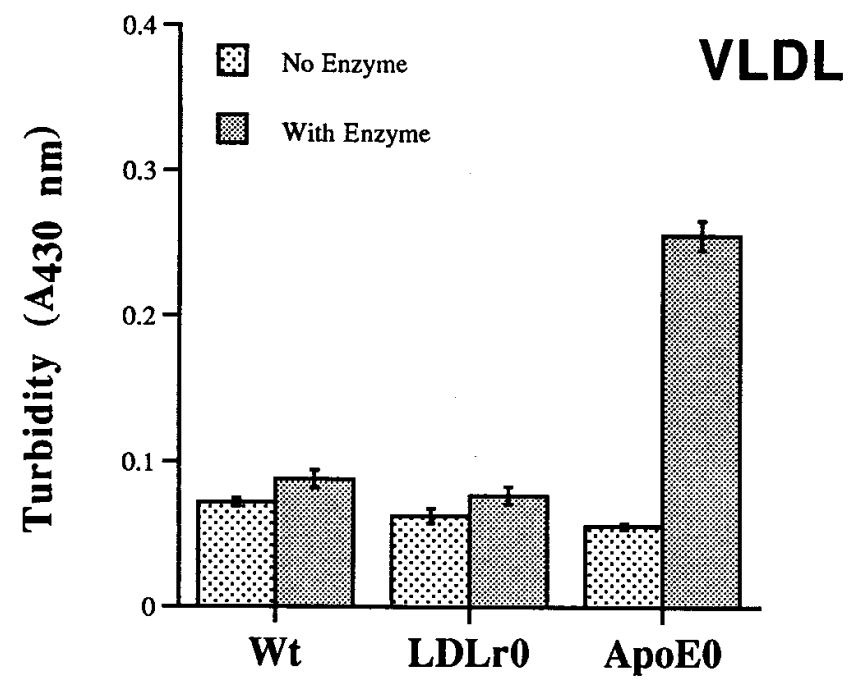

there was no difference in lactate dehydrogenase activity between apoE0 and Wt mice (Fig. $3 \mathrm{~B}$ ). Since the mouse Lcb2 subunit of SPT has been cloned (28), we used the mouse-specific 3 '-end cDNA sequence as a probe to perform an RNase protection assay for the Lcb2 subunit. As shown in Fig. 4, there was no difference in mRNA level of the Lcb2 subunit in apoE0 and Wt mice, suggesting that increased SPT activity in apoE0 mice is posttranscriptional.

We next sought to determine if enrichment of the lipoproteins from apoE0 mice with SM might contribute to the atherogenicity of these particles. As mentioned above, subendothelial lipoprotein aggregation is an important event in atherogenesis and foam cell formation $(12,15)$, and there is evidence to suggest that hydrolysis of lipoprotein SM by an arterial wall SMase may lead to lipoprotein aggregation (6). Thus, we reasoned that enrichment of lipoproteins with SM might increase their susceptibility to SMase-induced aggregation by increasing substrate availability to the enzyme (6). To test this idea, we used the S-SMase, which is secreted by macrophages and endothelial cells, and is a leading candidate for the arterial wall SMase that is known to act on subendothelial lipoproteins (see Introduction). As shown in Fig. 5, VLDL (top) and LDL (bottom) from apoE0 mice were aggregated after treatment with S-SMase, whereas these lipoproteins from Wt or LDLr0 mice did not aggregate. To assess possible involvement of apoE in lipoprotein aggregation after SMase treatment, we performed another aggregation experiment in which apoE0-

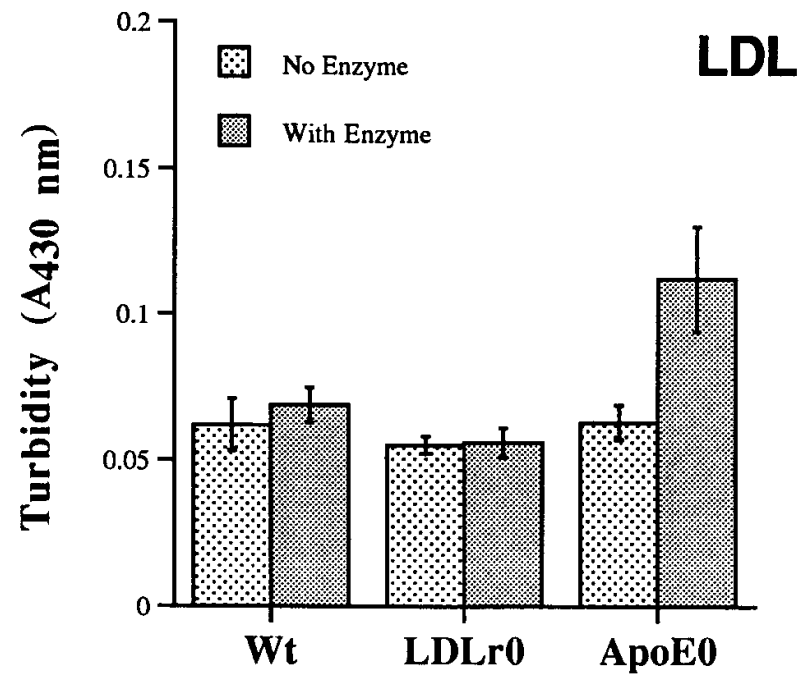

Figure 5. In vitro aggregation of atherogenic lipoproteins induced by macrophage-derived S-SMase. VLDL $(\mathrm{d}<1.006 \mathrm{~g} / \mathrm{ml})$ and LDL $(\mathrm{d}=$ $1.006-1.063 \mathrm{~g} / \mathrm{ml}$ ) were isolated from apoE0, LDLr0, and Wt mice. $4 \mu \mathrm{g}$ (by cholesteryl ester mass) VLDL or LDL was incubated with $25 \mu \mathrm{l}$ macrophage culture medium containing S-SMase in $0.1 \mathrm{M}$ Tris$\mathrm{HCl}$ buffer, $\mathrm{pH} 7.2$ at $37^{\circ} \mathrm{C}$, for $4 \mathrm{~h}$. The turbidity of samples was evaluated by measurement of $\mathrm{OD}$ at 430 . These results are representative of three similar experiments. ( $A$ ) VLDL aggregation; (B) LDL aggregation. 


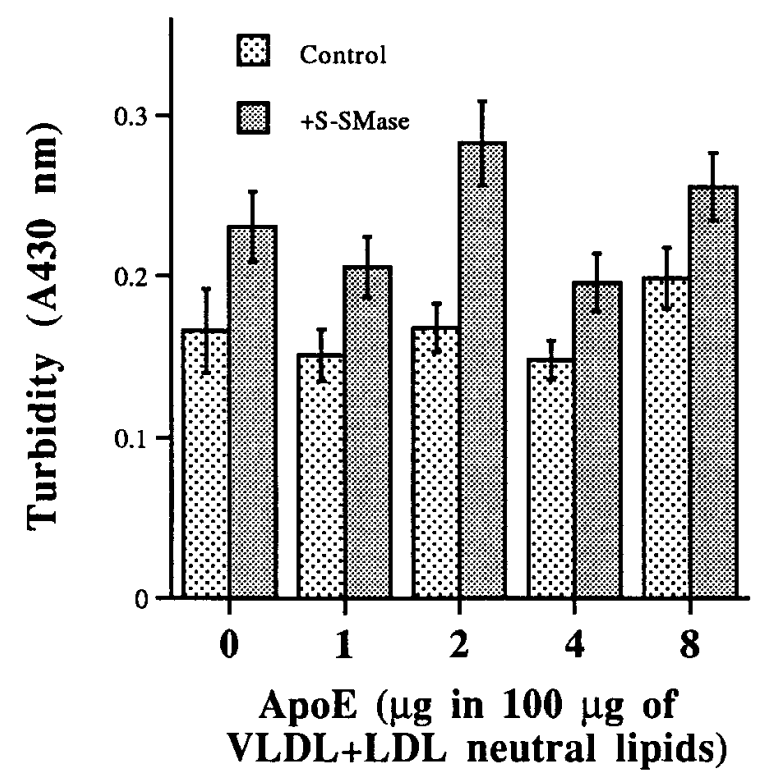

\section{$\begin{array}{lllll}\text { ApoB/ApoE } & 9: 1 \quad 6: 1 \quad 4: 1 \quad 4: 1\end{array}$}

Figure 6. Effect of apoE supplementation on the in vitro aggregation of mouse lipoproteins by S-SMase. VLDL+LDL were isolated from apoE0 mice. To VLDL + LDL (200 $\mu \mathrm{g}$ neutral lipids), 2, 4, 8, and 16 $\mu \mathrm{g}$ recombinant human apoE3 were added, and the mixture was incubated at room temperature with gentle agitation for $30 \mathrm{~min}$. Under these conditions, almost all of the apoE is bound to the lipoproteins (46). Then, the VLDL+LDL was separated by ultracentrifugation as described in Methods, and the apoE in the lipoproteins was measured by SDS-PAGE. $4 \mu \mathrm{g}$ (by cholesteryl ester mass) VLDL + LDL was incubated with $25 \mu \mathrm{l}$ macrophage culture medium containing S-SMase in $0.1 \mathrm{M}$ Tris- $\mathrm{HCl}$ buffer, $\mathrm{pH} 7.2$, at $37^{\circ} \mathrm{C}$ for $16 \mathrm{~h}$. Turbidity was evaluated by measuring the $\mathrm{OD}$ of samples at $430 \mathrm{~nm}$. These results are representative of two similar experiments.

derived S-SMase. As shown in Fig. 7, enrichment of SM in apoE0-VLDL did enhance aggregation when treated with both bacterial SMase (Fig. 7 A) and mammalian SMase (Fig. 7 B). Furthermore, we enriched Wt-VLDL with different amounts of SM, and then used the lipoproteins to perform the aggregation assay using macrophage-derived S-SMase. As shown in Fig. 8, enrichment of SM in Wt-VLDL also enhanced aggregation after S-SMase treatment (Fig. 8). These results suggest that enrichment of VLDL with SM may increase their atherogenic potential.

\section{Discussion}

In this study, we demonstrated that plasma and lipoprotein SM concentration in apoE0 mice was markedly higher than in $\mathrm{Wt}$ mice. The fourfold enrichment of SM in lipoproteins isolated from apoE0 mice could be explained by a twofold increase in SM PR combined with a twofold decrease in FCR. By contrast, PC metabolism was relatively normal in apoE0 mice, reflecting intravascular metabolism by lipoprotein-processing enzymes that appear to compensate for delayed clearance of remnant lipoproteins (8). Enrichment of SM in lipoproteins of apoE0 mice resulted in a much higher tendency to be aggre-

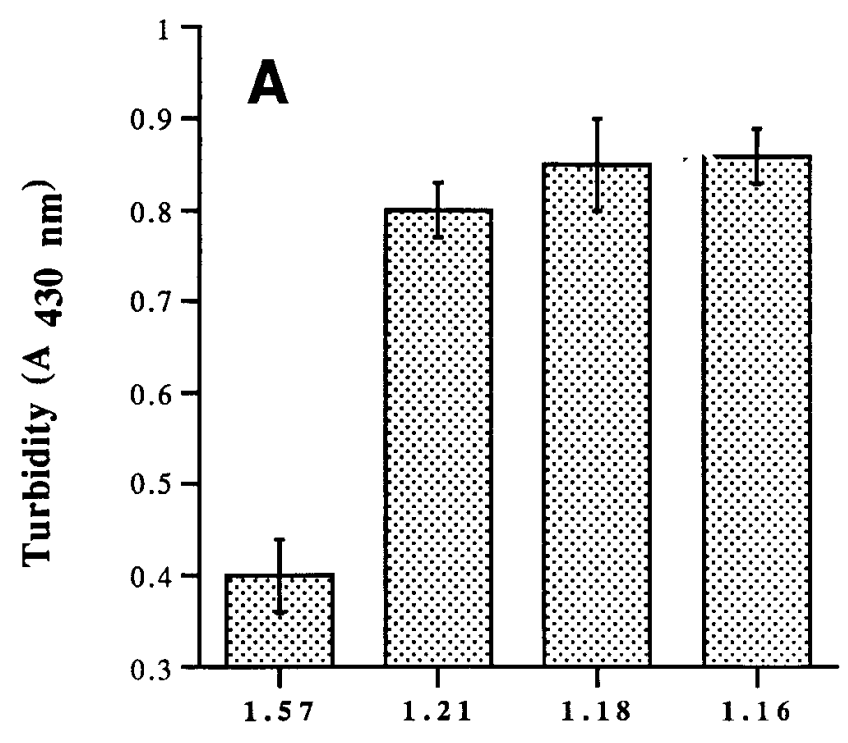

PC/SM

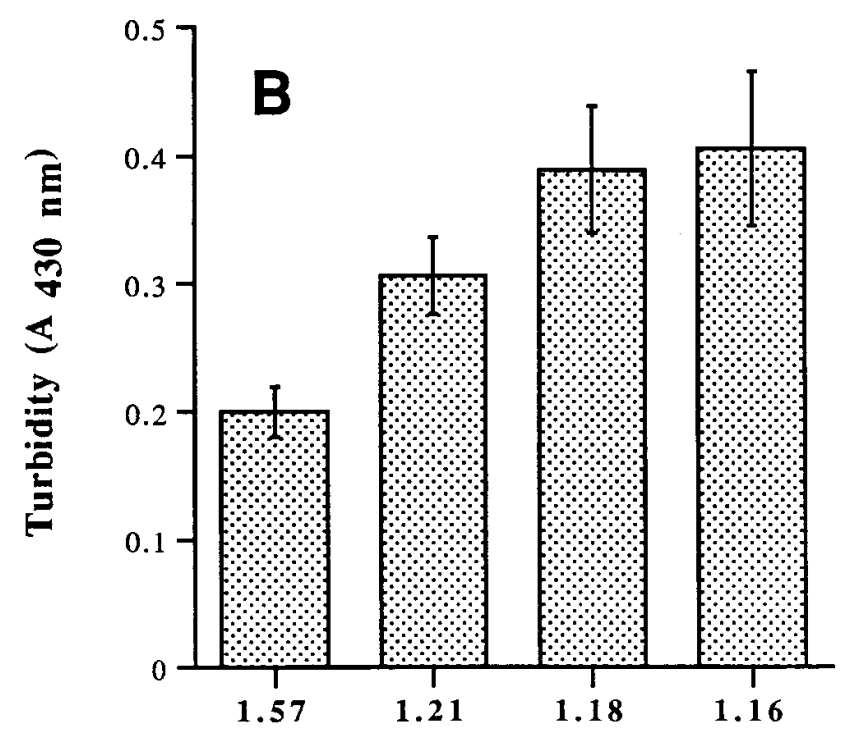

\section{$\mathbf{P C} / \mathrm{SM}$}

Figure 7. The effect of SM enrichment on VLDL aggregation by bacterial SMase and macrophage-derived S-SMase. VLDL $(\mathrm{d}<1.006 \mathrm{~g} / \mathrm{ml}$ fraction) from apoE0 mice was incubated with PC/SM/FC (1:1:0.5, $\mathrm{mol} / \mathrm{mol} / \mathrm{mol}$ ) vesicles for $0,1,2$, and $4 \mathrm{~h} .4 \mu \mathrm{g}$ (by cholesteryl ester mass) VLDL was incubated with $50 \mu \mathrm{U} / \mathrm{ml}$ bacterial SMase or $25 \mu \mathrm{l}$ macrophage culture medium containing S-SMase in $0.1 \mathrm{M}$ Tris-HCl buffer, $\mathrm{pH} 7.2$, at $37^{\circ} \mathrm{C}$ for $4 \mathrm{~h}$. Turbidity was evaluated by measuring the OD of samples at $430 \mathrm{~nm}$. (A) Bacterial SMase treatment; $(B)$ macrophage-derived S-SMase treatment. These results are representative of two similar experiments. 


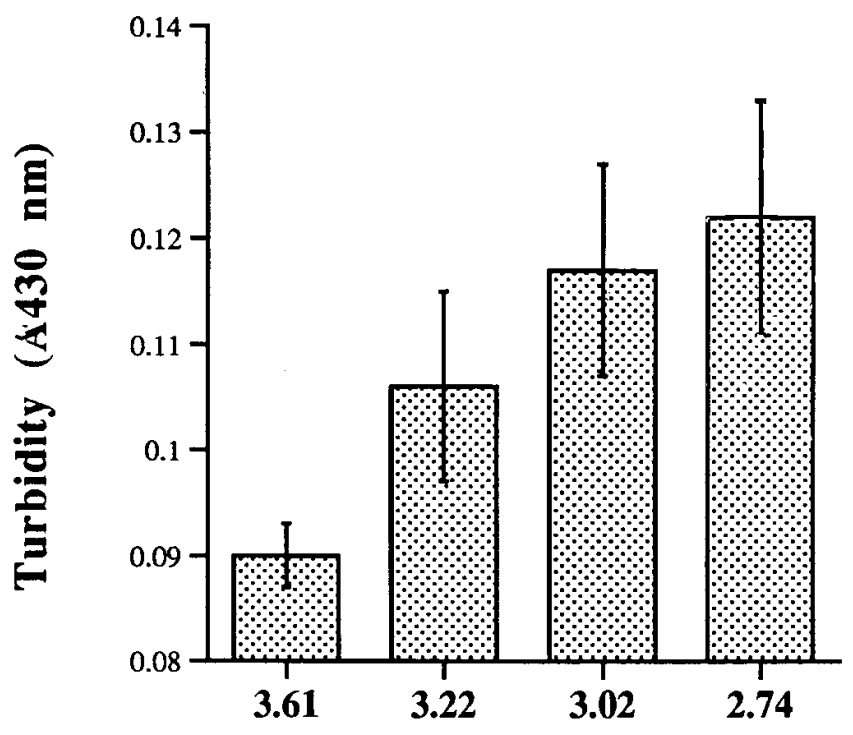

PC/SM

Figure 8. The effect of SM enrichment on Wt-VLDL aggregation induced by macrophage-derived S-SMase. VLDL + LDL $(\mathrm{d}<1.063 \mathrm{~g} / \mathrm{ml})$ from Wt mice was incubated with PC/SM/FC (1:1:0.5, $\mathrm{mol} / \mathrm{mol} / \mathrm{mol})$ vesicles for $0,1,2$, and $4 \mathrm{~h}$ as described in Methods. $4 \mu \mathrm{g}$ (by cholesteryl ester mass) VLDL was incubated with $25 \mu l$ macrophage culture medium containing S-SMase in $0.1 \mathrm{M}$ Tris- $\mathrm{HCl}$ buffer, $\mathrm{pH} 7.2$, at $37^{\circ} \mathrm{C}$ for $16 \mathrm{~h}$. Turbidity was evaluated by measuring the OD of samples at $430 \mathrm{~nm}$. These results are representative of two similar experiments.

gated after SMase treatment compared with Wt mice. Thus, deranged SM metabolism may be a factor promoting atherosclerosis in apoE0 mice, and in other settings where SM accumulates in atherogenic lipoproteins (4). We also speculate that apoE could play an essential role in disposition of SM arising from cell membrane turnover in the central nervous system.

The decreased FCR of plasma SM, reflected both in VLDL and HDL, indicates the essential role that apoE has in plasma SM catabolism. Hepatic clearance of SM-carrying remnants of triglyceride-rich lipoproteins, as well as large HDL, is known to involve recognition of apoE by hepatic LDLr and LRP (35). Surprisingly, however, mice with these receptors deleted by induced mutation showed no evidence of SM enrichment of lipoproteins (Table IV). This result suggests the existence of an additional clearance mechanism that can compensate for the lack of LDLr and LRP activity. Recently, a novel member (LR11) of the LDL receptor gene family has been described (37). Involvement of LR11 in hepatic SM-rich lipoprotein clearance deserves further investigation. Although we cannot rule out involvement of VLDL receptor and apoE receptor 2 (also members of the LDLr gene family), involvement is unlikely since hepatic expression of both mRNAs is very low $(38,39)$. It is also possible that lack of apoE might interfere with the clearance of lipoproteins by hepatic proteoglycans. The role of heparin sulphate proteoglycans has been shown by several groups for LPL- (40) and apoE-mediated lipoprotein uptake (41). The principle of concentration of lipoproteins on the cell surface through binding to proteoglycans and subsequent internalization by specific receptors or proteoglycans is currently a widely accepted model for lipoprotein clearance (35).

Unlike other phosphoglycerides, SM is not chemically degraded in the plasma compartment (42). In contrast to SM, plasma PC was cleared relatively normally in apoE0 mice. The differential metabolism is due to intravascular catabolism of PC that does not depend on apoE, as shown by the fact that $\mathrm{PC}$ ethers, that are not susceptible to cleavage at the sn- 1 or sn-2 position by HL and LCAT, respectively, had the same FCR as SM. It is known that SM is a physiological inhibitor of LCAT (31) and a nonsubstrate for HL (30). These observations partly explain the low $\mathrm{PC} / \mathrm{SM}$ ratio of plasma lipoprotein in apoE0 mice.

The increase in plasma SM was also associated with an increase in activity of hepatic SPT, suggesting increased hepatic SM synthesis. Relatively little is known about regulation of sphingolipid synthesis. Several lines of evidence suggest that SPT catalyzes the rate-limiting step in forming the SM precursor ceramide, and that other enzymes then determine partitioning of the ceramide into different classes of complex sphingolipids. SPT activity correlates well with the amount of tissue sphingolipids (43), and in rat liver hepatocytes, the level of precursors for long-chain base formation was related to the level of SM (44). Recently, both the mouse and human cDNA encoding the Lcb2 subunit of SPT have been identified (28). We found that there was no difference in mRNA abundance of the Lcb2 subunit of SPT in apoE0 and Wt mice (Fig. 4), suggesting that the increase of SPT activity in apoE0 mice might be posttranscriptionally mediated. This process may be analogous to posttranscriptional regulation of cytidylyl transferase activity during PC biosynthesis (45).

Increased SM content in VLDL and LDL in apoE0 mice may be relevant to atherogenesis in these animals. After treatment with macrophage-derived S-SMase, the VLDL and LDL from apoE0 mice were markedly aggregated (Fig. 5). This property seemed to reflect increased SM content since LDL or VLDL from Wt and LDLr0 mice did not show similar aggregation, and manipulation of VLDL in vitro to increase SM enhanced aggregation further, while changes in apoE content had no effect (Figs. 5-8).

Lipoprotein SM content might be an important indicator of atherogenicity. The VLDL of hypercholesterolemic rabbits on an atherogenic diet shows a fivefold enrichment with SM (4), and the PC/SM ratio is decreased in hyperlipidemic human serum (46). Accumulation of SM in atherosclerotic lesions can reach $75 \%$ of the total phospholipid content (12). This result could reflect local changes in synthesis as well as accumulation of SM-rich remnant lipoproteins. Lesional LDL is markedly enriched in SM, which could be an important factor enhancing its reactivity with SMase (6). The marked changes in remnant lipoprotein PC/SM ratio determined in this study may enhance the atherogenicity of these particles by increasing their reaction with arterial wall SMase. This study suggests that the PC/ SM ratio might be an independent indicator of the atherogenicity of plasma lipoproteins.

\section{Acknowledgments}

We thank Dr. Rajasekhar Ramakrishnan for helpful discussions and Dr. Richard Deckelbaum for providing recombinant apoE. The LDLr0 + LRP0 mouse plasma was a generous gift from Dr. J. Herz. 
This study was supported by National Institutes of Health grants HL-56984 (Specialized Center of Research in Molecular Medicine and Atherosclerosis). Dr. Tae-Sook Jeong was supported by a Korean Science and Engineering Foundation Postdoctoral Training grant.

\section{References}

1. Phillips, G.B., and J.T. Dodge. 1967. Composition of phospholipids and of phospholipid fatty acids of human plasma. J. Lipid Res. 8:676-681.

2. Subbaiah, P.V., M.H. Davidson, M.C. Ritter, W. Buchanan, and J.D. Bagdade. 1989. Effects of dietary supplementation with marine lipid concentrate on the plasma lipoprotein composition of hypercholesterolemic patients. Atherosclerosis. 79:157-166.

3. Lane, J.T., P.V. Subbaiah, M.E. Otto, and J.D. Bagdade. 1991. Lipoprotein composition and HDL particle size distribution in women with non-insulindependent diabetes mellitus and the effects of probucol treatment. J. Lab. Clin. Med. 118:120-128.

4. Rodriguez, A.L., G.C. Ghiselli., D. Torreggiani, and C.R. Sirtori. 1976. Very low density lipoproteins in normal and cholesterol-fed rabbits: lipid and protein composition and metabolism. Part 1: chemical composition of very low density lipoprotein in rabbits. Atherosclerosis. 23:73-83.

5. McCandless, E.L., and D.B. Zilversmit. 1956. The effect of cholesterol on the turnover of lecithin, cephalin and sphingomyelin in rabbits. Arch. Biochem. Biophys. 62:402-410.

6. Schissel, S.L., J. Tweedie-Hardman, J.H. Rapp, G. Graham, K.J. Williams, and I. Tabas. 1996. Rabbit aorta and human atherosclerotic lesions hydrolyze the sphingomyelin of retained low density lipoprotein. J. Clin. Invest. 98:1455-1464.

7. Smith, J.D., E. Trogan, M. Ginsberg, C. Grigtaux, J. Tian, and M. Miyata. 1995. Decreased atherosclerosis in mice deficient in both macrophage colonystimulating factor (op) and apolipoprotein E. Proc. Natl. Acad. Sci. USA. 92: 8264-8268.

8. Plump, A.S., and J.L. Breslow. 1995 Apolipoprotein E and the apolipoprotein E-deficient mouse. Annu. Rev. Nutr. 15:495-518.

9. Plump, A.S., J.D. Smith, T. Hayek, K. Aalto-Setala, A. Walsh, J.G. Verstuyft, E.M. Rubin, and J.L. Breslow. 1992. Severe hypercholesterolemia and atherosclerosis in apolipoprotein E-deficient mice created by homologous recombination in ES cells. Cell. 71:343-353.

10. Zhang, S.H., R.L. Reddick, J.A. Piedrahita, and N. Maeda. 1992. Spontaneous hypercholesterolemia and arterial lesions in mice lacking apolipoprotein E. Science. 258:468-471.

11. Gordon, I., E. Grauer, I. Genis, E. Sehayek, and D.M. Michaelson. 1995. Memory deficits and cholinergic impairments in apolipoprotein E-deficient mice. Neurosci. Lett. 199:1-4.

12. Williams, K.J., and I. Tabas. 1995. The response-to-retention hypothesis of early atherosclerosis. Arterioscler. Thromb. Vasc. Biol. 15:551-561.

13. Witztum, J.L., and D. Steinberg. 1991. Role of oxidized low density lipoprotein in atherogenesis. J. Clin. Invest. 88:1785-1792.

14. Yla-Herttuala, S., W. Palinski, M.E. Rosenfeld, S. Parthasarathy, T.E. Carew, S. Butler, J.L. Witztum, and D. Steinberg. 1989. Evidence for the presence of oxidatively modified low density lipoprotein in atherosclerotic lesions of rabbit and man. J. Clin. Invest. 84:1086-1095.

15. Nievelstein, P.F.E.M., A.M. Fogelman, G. Mottino, and J.S. Frank. 1991. Lipid accumulation in rabbit aortic intima 2 hours after bolus infusion of low density lipoprotein. Arterioscler. Thromb. 11:1795-1805.

16. Ross, R. 1993. The pathogenesis of atherosclerosis: a perspective for the 1990s. Nature. 362:801-809.

17. Hoff, H.F., and R.E. Morton. 1985. Lipoproteins containing apoB extracted from human aortas: structure and function. Ann. NY Acad. Sci. 454: 183-194.

18. Guyton, J.R., and K.F. Klemp. 1996. Development of the lipid-rich core in human atherosclerosis. J. Lipid Res. 16:4-11.

19. Schissel, S.L., H.E. Schuchman, K.J. Williams, and I. Tabas. 1996. $\mathrm{Zn}^{2+}$ stimulated sphingomyelinase is secreted by many cell types and is a product of the acid sphingomyelinase gene. J. Biol. Chem. 271:18431-18436.

20. Jiang, X.C., O.L. Francone, C. Bruce, R. Milne, J. Mar, A. Walsh, J.L. Breslow, and A.R. Tall. 1996. Increased pre $\beta$-high density lipoprotein, apolipoprotein AI, and phospholipid in mice expressing the human phospholipid transfer protein and human apolipoprotein AI transgenes. J. Clin. Invest. 96:23732380.

21. Pownall, H., D. Hickson-Bick, and J.B. Massey. 1991. Effects of hydrophobicity on turnover of plasma high density lipoproteins labeled with phosphatidylcholine ester in the rat. J. Lipid Res. 32:793-800.

22. Bligh, E.G., and W.J. Dyer. 1959. A rapid method for total lipid extraction and purification. Can. J. Biochem. Physiol. 37:911-917.

23. Bartlett, G.R. 1959. Phosphorus assay in column chromatography. J. Biol. Chem. 234:466-468.

24. Takayama, M., S. Itoh, T. Nagasaki, and I. Tanimizu. 1977. A new enzymatic method for determination of serum choline-containing phospholipids.
Clin. Chim. Acta. 79:93-98.

25. Matthews, C.M.E. 1957. The theory of tracer experiments with ${ }^{131}$ I-labeled plasma proteins. Phys. Med. Biol. 2:36-53.

26. Brinton, E.A., S. Eisenberg, and J.L. Breslow. 1994. Human HDL cholesterol levels are determined by apoAI fractional catabolic rate, which correlates inversely with estimates of HDL particle size. Arterioscler. Thromb. 14: 707-720.

27. Williams, R.D., E. Wang, and A.H. Merrill. 1984. Enzymology of longchain base synthesis by liver: characterization of serine palmitoyltransferase in rat liver microsomes. Arch. Biochem. Biophys. 228:282-291.

28. Nagiec, M.M., R.L. Lester, and R.C. Dickson. 1996. Sphingolipid synthesis: identification and characterization of mammalian cDNAs encoding the Lcb2 subunit of serine palmitoyltransferase. Gene. 177:237-241.

29. Melton, D.A., P.A. Krieg., M.R. Rebagliati., T. Maniatis, and M.R. Green. 1984. Efficient in vitro synthesis of biologically active RNA and RNA hybridization probes from plasmids containing a bacteriophage SP6 promoter. Nucleic Acids Res. 12:7035-7056.

30. Laboda, H.M., J.M. Jane, and M.C. Phillips. 1986. Hydrolysis of lipid monolayers and the substrate specificity of hepatic lipase. Biochim. Biophys. Acta. 876:233-242.

31. Subbaiah, P.V., and M. Liu. 1993. Role of sphingomyelin in the regulation of cholesterol esterification in the plasma lipoproteins. J. Biol. Chem. 268: 20156-20163.

32. Pownall, H.J., Q. Pao, and J.B. Massey. 1985. Acyl chain and head group specificity of human plasma lecithin:cholesterol transferase: separation of matrix and molecular specificities. J. Biol. Chem. 260:2146-2152.

33. Herz, J., S.Q. Qiu, A. Oesterle, H.V. DeSilva, S. Shafi, and R.J. Havel. 1995. Initial hepatic removal of chylomicron remnants is unaffected but endocytosis is delayed in mice lacking the low density lipoprotein receptor. Proc. Natl. Acad. Sci. USA. 92:4611-4615.

34. Aalto-Setala, K., E.A. Fisher, X. Chen, T. Chajek-Shaul, T. Hayek, R. Zechner, A. Walsh, R. Ramakrishnan, H.N. Ginsberg, and J.L. Breslow. 1992. Mechanism of hypertriglyceridemia in human apolipoprotein (apo) CIII transgenic mice. Diminished very low density lipoprotein fractional catabolic rate associated with increased apoCIII and reduced apoE on the particles. J. Clin. Invest. 90:1889-1990.

35. Beisiegel, U. 1995. Receptors for triglyceride-rich lipoprotein and their role in lipoprotein metabolism. Curr. Opin. Lipidol. 6:117-122.

36. Merrill, A.H., and D.D. Jones. 1990. An update of the enzymology and regulation of sphingomyelin metabolism. Biochim. Biophys. Acta. 1044:1-12.

37. Yamazaki, H., H. Bujo, J. Kusunoki, K. Seimiya, T. Kanaki, N. Morisaki, W.J. Schneider, and Y. Saito. 1996. Elements of neural adhesion molecules and a yeast vacuolar protein sorting receptor are present in a novel mammalian low density lipoprotein receptor family member. J. Biol. Chem. 271: 24761-24768.

38. Oka, K., K.W. Taung., M. Sullivan, E. Lindsay., A. Baldini, and L. Chan. 1994. Human very-low-density lipoprotein receptor complentary DNA and deduced amino acid sequence and localization of its gene (VLDLR) to chromosome band 9p24 by fluorescence in situ hybridization. Genomics. 20: 298-300.

39. Kim, D.H., K. Magoori, T.R. Inoue, C.C. Mao, H.J. Kim, H. Suzuki, T. Fujita, Y. Endo, S. Saeki, and T.T. Yamamoto. 1997. Exon/intron organization, chromosome localization, alternative splicing, and transcription units of the human apolipoprotein E receptor 2 gene. J. Biol. Chem. 272:8498-8504.

40. Beisiegel, U., A. Krapp., W. Weber, and G. Olivercrona. 1994. The role of alpha ${ }_{2} \mathrm{M}$ receptor/LRP in chylomicron remnant metabolism. In Biology of Alpha2-macroglobulin, its Receptor and Related Proteins. B.W. Feinmann, S.L. Gonias, J.P. Quigley, and D.K. Strickland, editors. New York Academy of Sciences, New York. 53-69.

41. Ji, Z.S., S. Fazio, and R.W. Mahley. 1994. Variable heparan sulfate proteoglycan binding of apolipoprotein $\mathrm{E}$ variants may modulate the expression of type III hyperlipoproteinemia. J. Biol. Chem. 269:13421-13428.

42. Myher, J.J., A. Kuksis, and S. Pine. 1989. Molecular species of glycerophospholipids and sphingomyelins of human plasma: comparison to red blood cells. Lipids. 24:408-418.

43. Merrill, A.H., D.W. Dixon, and R.D. Williams. 1985. Activities of serine palmitoyltransferase in microsomes from different rat tissues. J. Lipid Res. 26 : 617-622.

44. Messmer, T.O., E. Wang., V.L. Stevens, and A.H. Merrill. 1989. Sphingolipid biosynthesis by rat liver cells: effects of serine, fatty acids and lipoproteins. J. Nutr. 119:534-538.

45. Shiratori, Y., A.K. Okwu, and I. Tabas. 1994. Free cholesterol loading of macrophages stimulates phosphatidylcholine biosynthesis and up-regulation of CTP: phosphocholine cytidylyltransferase. J. Biol. Chem. 269:11337-11348.

46. Noel, C., Y.L. Marcel, and J. Davignon. 1972. Plasma phospholipids in the different types of primary hyperlipoproteinemia. J. Lab. Clin. Med. 79:611-621.

47. Granot, E., B. Schwiegelshohn, I. Tabas, M. Gorecki, T. Vogel, Y.A. Carpentier, and R.J. Deckelbaum. 1994. Effects of particle size on cell uptake of model triglyceride-rich particles with and without apoprotein E. Biochemistry. 33:15190-15197. 